\title{
Countermeasures for Risk Management of Supply Chain Finance
}

\author{
Chen Lihong \\ School of Economics and Law \\ Hubei University of Technology \\ Wuhan, P. R. China \\ hlchen456@163.com
}

\begin{abstract}
As a new type of service product provided by bank, supply chain finance is of large development potential compared with non-supply chain finance. There exist risks such as the moral risk of the core enterprise, the internal operating risk of the bank, the pledging risk of the logistics enterprise's warehouse receipt, the risk of transferring information and the accumulating risk of the supply chain finance. This paper studied the risks of supply chain finance and explored the countermeasures on the base of theory of supply chain and theory of commercial bank's risk management, the conclusion is that managing the risks of supply chain finance needs to formulate strict standard for choosing core enterprise, improve operation management, choose pledged assets prudently, strengthen informationization construction to establish effective platform for exchanging information and strengthen management to whole supply chain.
\end{abstract}

Keywords- supply chain finance; financing mode; risk; risk management

\section{INTRODUCTION}

Supply chain finance is a new financing mode tailored specially for SME (small and medium sized enterprise) by financial institutions. The financial institution develops synthesis credit for SME from the supply chain angle and transforms risk management aimed at single enterprise to risk management of the whole supply chain. Supply chain finance breaks the bank's old thought model of inspecting single enterprise 's static state credit, but takes the upstream to downstream enterprise as a whole to design effective financing plan according to the chain relationship formed in the transaction and industrial characters. The supply chain finance can not only solve SME's capital problem, but also promote the competitive power of the entire supply chain.

Supply chain finance alleviates the difficulty of SME financing, it is of the following characters: (1) It derivates from supply chain foundation. from the angle of the supply chain, with the aid of the core enterprise's credit strength or recompenses degree of the single transaction and the circulation value of the cargo, the financial institution provides comprehensive financial services for single enterprise or upstream to downstream enterprises in the supply chain. (2) It changes the traditional financial service viewing angle of financial institutions. The bank pays more attention to the transaction risk of the whole supply chain based on the supply chain finance: the risk appraisal is no longer limited to the main body, but more to supply chain and the transaction, so the supply chain finance reduces the financial institutions limit to SME, more SME enter the range of the bank's service. (3) Participants are diversified. In the traditional SME financing way, participates are only credit organizations and SME, sometimes needs the third party guarantor's participation, but in the supply chain financing pattern, the participants not only includes the financial institution and the financing enterprise, but also includes the core enterprise, the upstream and downstream enterprise on the chain and the Logistics enterprise. Each participant plays different role, realizes high effective and the wins of the supply chain finance through coordinating mutually, sharing risk and income.

Although supply chain finance is an effect way to relieve financing predicament of SME and extends the bank's business range, there are still many risks hindering the development of supply chain finance. In this paper, we are going to compare the differences between the supply chain finance and non-supply chain finance, analyze the risks exist in the process of supply chain financing and explore countermeasures to manage the risks.

\section{DIFFERENCES BETWEEN SUPPLY CHAIN FINANCE AND NON-SUPPLY CHAIN FINANCE}

\section{A. Supply Chain Finance Modes}

At present, the supply chain finance modes provided by bank of our country are roughly divided into three types: they are receivable account financing, prepayment account financing and movable property hypothecated financing.

Receivable account financing mode is that the upper reaches SME of the core enterprise in the supply chain gets finance from the bank with the overdue account receivable, generally it provides finance for the upper reaches SME (creditor's rights enterprise) of the supply chain. The upper reaches SME, core enterprise (debt enterprise) and bank participates in this financing course. The core enterprise plays a counter guarantee role in the whole operation. It will undertake the responsibility to compensate the lost of the bank, once the financing enterprise goes wrong. Bank needs to carry on the risk assessment before it agrees to grant a credit loan to the upper reaches SME, paying close attention to refund ability of core enterprise, trade risk and the operation state of the whole supply chain especially, not 
merely carrying on credit assessment to the upper reaches SME own.

The payment term that downstream SME obtains from the core enterprise is often short, sometimes the SME needs to pay the bill in advance, SME having difficulty of shortterm fund circulating can use payable account financing mode. The prepayment account financing mode is a financing business that under the prerequisite of the core enterprise promising buy-back, SME apply to financial institution for the hypothecate loan with the set warehouse receipt appointed by the financial institution, the right of picking up goods is controlled by financial institution.

Movable property hypothecated financing mode is that the financial institution accepts the movable property hypothecating and releases the loan to the SME with the aid of the guarantees of the core enterprise and supervision of the logistics enterprise.

\section{B. Differences between Supply Chain Finance and Non- supply Chain Finance}

There are many differences between supply chain finance and non-supply chain finance. The differences are shown in Tab. I

TABLE I. DIFFERENCES BETWEEN SUPPLY CHAIN FINANCE AND NON-SUPPLY CHAIN FINANCE

\begin{tabular}{|c|c|c|}
\hline $\begin{array}{l}\text { Comparison } \\
\text { Objects }\end{array}$ & \multirow{2}{*}{ Supply Chain Finance } & \multirow{2}{*}{$\begin{array}{c}\text { Non-supply Chain } \\
\text { Finance }\end{array}$} \\
\hline $\begin{array}{l}\text { Comparison } \\
\text { Contents }\end{array}$ & & \\
\hline Credit subject & $\begin{array}{l}\text { Single enterprise or } \\
\text { enterprise group on the } \\
\text { chain }\end{array}$ & Single enterprise \\
\hline Rating method & Debtor rating or debt rating & Debtor rating \\
\hline Rating range & $\begin{array}{l}\text { Enterprise and the entire } \\
\text { supply chain }\end{array}$ & Enterprise itself \\
\hline Credit conditions & $\begin{array}{c}\text { Chattel mortgage or cargo } \\
\text { mortgage and so on }\end{array}$ & $\begin{array}{c}\text { Fixed assets } \\
\text { mortgage or third } \\
\text { party guarantees }\end{array}$ \\
\hline $\begin{array}{l}\text { Bank participation } \\
\text { degree }\end{array}$ & $\begin{array}{c}\text { tracking enterprise managing } \\
\text { process dynamically }\end{array}$ & $\begin{array}{c}\text { Focus on enterprise } \\
\text { itself statically }\end{array}$ \\
\hline $\begin{array}{l}\text { Risk undertaken } \\
\text { by bank }\end{array}$ & low & High \\
\hline $\begin{array}{l}\text { Bank's service } \\
\text { efficiency }\end{array}$ & $\begin{array}{l}\text { Meeting the need for } \\
\text { short-term capital }\end{array}$ & $\begin{array}{l}\text { The procedure is } \\
\text { tedious, the } \\
\text { efficiency is low }\end{array}$ \\
\hline $\begin{array}{l}\text { Bank's service } \\
\text { result }\end{array}$ & $\begin{array}{l}\text { Promoting enterprise and the } \\
\text { whole supply chain } \\
\text { competitive ability }\end{array}$ & $\begin{array}{l}\text { Alleviating fund } \\
\text { difficulty of single } \\
\text { enterprise for } \\
\text { a while }\end{array}$ \\
\hline
\end{tabular}

III. RISKS OF SUPPLy CHAIN FiNANCE

\section{A. Moral Risk of the Core Enterprise}

The core enterprise is the critical factor to decide the risk of the supply chain finance because of its size and strength. Generally speaking, if the core enterprise and SME benefit mutually, the marginal credit of SME can be improved to the same level as the core enterprise, but if the core enterprise taking advantage of the advantage position in the negotiation takes for their own behavior on business conditions such as delivery, price and credit date in order to maximize the short-term benefits, which can cause SME financial strain, thus SME have to finance from bank. Once SME get the bank's fund, the money tension of the supply chain is eased, the core enterprise will occupy SMEs fund further, causing supply chain risk because of supply chain being unstable.

\section{B. Internal Operating Risk of the Bank}

The innovation of the supply chain finance is that taking warehouse receipt even logistics as a pledge object, which involves the price assessment for warehouse receipt and logistics process. In the one hand, fluctuations in prices will result in up valuation or devaluation of the pledge object, which leads to the collateral risk, On the other hand, if the operation staff of the bank cheat or operate miss, they don't use scientific and just method to ensure the accuracy of assessment and estimate, which can lead to the loss of the bank's benefits.

\section{Pledging Risk of the Logistics Enterprise's Warehouse Receipt}

To the logistics enterprise, the risks originate in customer credit, the choice and storage for pledging cargo and internal operation. The types of the risk conclude: (1) Customer credit risk. Customer's business ability, business amount and legality of the cargo origin are potential risk for logistic enterprise. There exists quality risk, if the enterprise makes up with bad good but takes good goods when rolling delivery. (2) Warehouse receipt risk. Warehouse receipt is the certificate for hypothecated loan and taking delivery of goods, it also is negotiable securities, but warehouse receipt opened by warehouse isn't standardized at present, for example, some warehouse even take warehouse list as pledge certificate or take delivery order as delivery certificate. (3) Risk of choosing warehouse receipt. Not all goods are suit for warehouse receipt pledge, the price and the quality of the goods change with the time in a period. (4) Risk of supervising goods. In the aspect of supervising goods, the asymmetrical, distorting and hysteretic information lead to decision mistake, which result in supervising risk of the pledge goods.

\section{Risk of Transferring Information}

Because every enterprise is an independent operation and management economic entity, actually the supply chain is a kind of unconsolidated enterprise alliance which doesn't sign agreement. When the supply chain scale is enlarging, the structure of the supply chain is becoming complicate: the chance to mistake information will increase. The delay of information transfer happens because there are many layers to transfer information, information transferred delay leads to insufficiency communication between upstream and downstream enterprise, thus the divergence will emerge on production and customer 's need, the whole supply chain cannot meet the needs of market. This situation will transfer mistake information to bank, affecting the bank's judgment. 


\section{E. Accumulating Risk of Supply Chain Finance}

The most important character of the supply chain finance is that the financial institution looks for one heavy core enterprise among supplying chain and offers financial support for SME. Because bank pays more attention to transaction risk of whole supply chain and evaluates the whole trade, more SME get the loan even if a certain enterprise cannot reach some standards of bank, the bank will desalinize appraise to this SME own credit, only its trade with the core enterprise. Under the circumstance, once a certain enterprise has the financial problems, it will spread to the whole supply chain and cause greater financial disaster.

\section{COUNTERMEASURES TO MANAGEING RISKS}

\section{A. Formulating Strict Standard for Choosing Core Enterprise}

The bank should set up strict standard for choosing core enterprise in order to guard against core enterprise's moral risk, the bank needs to inspect core enterprise from following aspects ( Are shown in Tab.П)

TABLE II. INSPECTION ASPECT AND CONCRETE CONTNET

\begin{tabular}{|c|c|}
\hline Inspection Aspects & Concrete Contents \\
\hline $\begin{array}{c}\text { Core enterprise's operation } \\
\text { strength }\end{array}$ & $\begin{array}{c}\text { Stockholder's rights structure, main } \\
\text { business income from investment, tax } \\
\text { policy, debts, credit record, position in } \\
\text { industry, share of the market, development } \\
\text { potential }\end{array}$ \\
\hline $\begin{array}{c}\text { Core enterprise's ability } \\
\text { to manage upstream to } \\
\text { downstream enterprise }\end{array}$ & $\begin{array}{c}\text { Exit and access management to supplier } \\
\text { and distributor, } \\
\text { Preferential policy for supplier and } \\
\text { distributor for example: order security, } \\
\text { rebate, prince compensation, } \\
\text { marketing support }\end{array}$ \\
$\begin{array}{c}\text { Incentive And restraint mechanisms to } \\
\text { supplier and distributor, }\end{array}$ \\
$\begin{array}{c}\text { Core enterprise's ability } \\
\text { to assist bank }\end{array}$ & $\begin{array}{c}\text { Information construction degree of core } \\
\text { enterprise } \\
\text { The cooperation condition between bank } \\
\text { and core enterprise. }\end{array}$ \\
\hline
\end{tabular}

\section{B. Improving Operation Management to Prevent Operation Risk}

No matter bank or logistics enterprise should formulate strict operation rules and supervise procedure according to different service methods. Logistics enterprise should improve level of managing warehouse and level of informationization for warehouse, setting up perfect risk control scheme for warehousing and delivery. The bank should improve information acquisition system for customer, checking system for credit information, rating system for credit used and so on, to stop risk because of internal management loophole and lacking of standardization, meanwhile, commercial bank can cooperate with some agencies to control over risk of supply chain finance business, for example cooperate with some e-commerce platform and small enterprise security department supported by government, establishing risk compensation fund: once capital can't recycle on schedule, it can be paid by compensation fund, at the same time bank recover debts.

\section{Choosing Pledged Assets Prudently}

As material safeguard for bank credit, the realizable ability of pledge asset is an important index to measuring credit safety. In order to ensure the realizable ability, bank must cooperation with professional assets evaluating organization and logistics enterprise, assessing pledged asset objectively and choosing different inspected content to different assets (Are shown in Tab.III).

TABLE III. Inspectied Contnet to Different Pledged Assets

\begin{tabular}{|c|c|}
\hline Pledged Assets & Inspected Contents \\
\hline Inventory & $\begin{array}{c}\text { Good quality and sufficient quantity, } \\
\text { high liquidity, clear cargo rights } \\
\text {,easy to store }\end{array}$ \\
\hline Accounts Receivable & $\begin{array}{c}\text { Contract based by account } \\
\text { receivable should be real and } \\
\text { effective, }\end{array}$ \\
Accounts Receivable should be in \\
the validity period \\
Accounts Receivable can be \\
negotiated by endorsement, \\
Goods resource adequacy of \\
upstream enterprise \\
Compensation ability of upstream \\
enterprise \\
Prepayment \\
Repurchase ability and wish of \\
upstream enterprise
\end{tabular}

D. Strengthening Informationization Construction to Establish Effective Platform for Exchange Information

The bank should strengthen input for information management hardware and train professional personnel in order to ensure the coordination of logistics, information flow and capital flow in the supply chain finance, establishing date platform for information, goods and capital by means of international technology and software, for example, ERP system platform , EDI , things network technology and so on. By means of information technology, connect upstream and downstream enterprise together: strengthen the information communication among enterprises in the supply chain to reduce information transfer risk

\section{E. Strengthening Management to Supply Chain}

First, choosing appropriate supply chain. Generally speaking, the industrial chain selected by bank should have following characters: industrial chain is complete, industrial order is good and the degree of cooperation between industrial and bank is high. Second, helping core enterprise choose supply chain member enterprise, bank should guide the core enterprise to regard the credit as an important standard for choosing member enterprise. Bank should develop online supply chain finance, the trade information, security information and supervision information of the 
supply chain enterprises can be obtained from online supply chain finance platform. Third, introducing the encouragement and discipline mechanism in supply chain finance, bank and core enterprise should assess member enterprise after a period of operation: raising the credit line for those enterprises of good behavior and forcing insincerity enterprise withdraw from supply chain.

\section{CONCLUSION}

Supply chain finance is not only a new way to relieve financing predicament of SME, but also is a new method to expand bank service product, since it comes into being, it gains general recognition of industrial sector and bank sector. There are three main supply chain finance mode, receivable account financing, prepayment account financing mode and movable property hypothecated financing, supply chain finance is of large development potential compared with non-supply chain finance. In the development process of supply chain finance, there exist risks such as core enterprise's moral risk, bank's internal operation risk, logistics enterprise's warehouse receipt pledging risk, information transfer risk and supply chain finance gathering risk. This paper studied the risks of supply chain finance and explored the countermeasures on the base of the theory of supply chain and the theory of commercial bank's risk management, the conclusion is that managing the risks of supply chain finance needs to formulate strict standard for choosing core enterprise, improve operation management , choose pledge prudently, strengthen informationization construction to establish effective platform for exchange information and strengthen management to whole supply chain.

\section{ACKNOWLEDGMENT}

The paper is one of research achievement of the doctor fund project of Hubei University of Technology (NO: BSQD0920) and Science \& Technology Project of Hubei Education Bureau. (NO: 2011jyte030)

\section{REFERENCES}

[1] Yang Jian, "Study on SME Financing Under the Supply Chain Finance," Communication of Finance and Accounting, 2010(7), pp.24-25(In Chinese)

[2] Yu Juying, "Study on Current Situation of SME Supply Chain Financing,” Modern Business, 2009(3), pp.185-186(In Chinese)

[3] Yang Yanzhong, "Risk Prevention in Supply Chain Finance of Commercial Bank,” Finance Forum, 2007(1), pp.42-45(In Chinese)

[4] Li Qin, Han Kai, "Status and Problems of Supply Chain Finance: on the basis of 93 Enterprises' investigation, ” Reform, 2009(6), pp.7885(In Chinese)

[5] Li Hanjun, "Discussing on Broblems of Commercial Bank Supply Chain Finance, " Assets and Finances in Administration and Intitution, 2011(5), pp.68-69(In Chinese)

[6] Chen Juan, “Advice for Development of Supply Chain Finance and Commercial Bank from System Perpective," Financial Aspect, 2011(8), pp.24-27(In Chinese)

[7] Xu Shengdao, Cheng Shaoqing, "Supply Chain Financing and Perfect ing Credit Evaluation Index System for SME, ” Credit Reference, 2011(2), pp.13-16(In Chinese) 